\title{
Chikungunya Virus Transmission at Low Temperature by Aedes albopictus Mosquitoes
}

\author{
B. M. C. Randika Wimalasiri-Yapa ${ }^{1,2} \mathbb{D}^{\mathbb{D}}$, Liesel Stassen ${ }^{1}$, Wenbiao Hu ${ }^{3}$, Laith Yakob ${ }^{4}$, \\ Elizabeth A. McGraw ${ }^{5}{ }^{(0}$, Alyssa T. Pyke ${ }^{6}{ }^{\circ}$, Cassie C. Jansen ${ }^{7}$, Gregor J. Devine ${ }^{8}$ and \\ Francesca D. Frentiu $1, *$ (1)
}

1 Institute of Health and Biomedical Innovation, School of Biomedical Sciences, Queensland University of Technology, Brisbane, QLD 4001, Australia

2 Department of Medical Laboratory Sciences, Faculty of Health Sciences, The Open University of Sri Lanka, Colombo 10250, Sri Lanka

3 Institute of Health and Biomedical Innovation, School of Public Health and Social Work, Queensland University of Technology, Brisbane, QLD 4059, Australia

4 Department of Disease Control, Faculty of Infectious \& Tropical Diseases, The London School of Hygiene \& Tropical Medicine, London WC1H 9SH, UK

5 Department of Entomology, Center for Infectious Disease Dynamics, Huck Institutes of the Life Sciences, Pennsylvania State University, State College, PA 16802, USA

6 Public Health Virology Laboratory, Forensic and Scientific Services, Queensland Health, Coopers Plains, QLD 4108, Australia

7 Communicable Diseases Branch, Queensland Health, Herston, QLD 4006, Australia

8 Mosquito Control Laboratory, QIMR Berghofer Medical Research Institute, Brisbane, QLD 4006, Australia

* Correspondence: francesca.frentiu@qut.edu.au; Tel.: +617-3138-6185

Received: 19 July 2019; Accepted: 10 September 2019; Published: 12 September 2019

\begin{abstract}
Aedes albopictus is an important vector of chikungunya virus (CHIKV). In Australia, Ae. albopictus is currently only known to be present on the islands of the Torres Strait but, should it invade the mainland, it is projected to spread to temperate regions. The ability of Australian Ae. albopictus to transmit CHIKV at the lower temperatures typical of temperate areas has not been assessed. Ae. albopictus mosquitoes were orally challenged with a CHIKV strain from either Asian or East/Central/South African (ECSA) genotypes $\left(10^{7} \mathrm{pfu} / \mathrm{mL}\right)$, and maintained at a constant temperature of either $18{ }^{\circ} \mathrm{C}$ or $28^{\circ} \mathrm{C}$. At 3- and 7-days post-infection (dpi), CHIKV RNA copies were quantified in mosquito bodies, and wings and legs using real time polymerase chain reaction (qRT-PCR), while the detection of virus in saliva (a proxy for transmission) was performed by amplification in cell culture followed by observation of cytopathic effect in Vero cells. Of the $\geq 95 \%$ of Ae. albopictus that survived to $7 \mathrm{dpi}$, all mosquitoes became infected and showed body dissemination of CHIKV at both temperatures and time points. Both the Asian and ECSA CHIKV genotypes were potentially transmissible by Australian Ae. albopictus at $28^{\circ} \mathrm{C}$ within 3 days of oral challenge. In contrast, at $18{ }^{\circ} \mathrm{C}$ none of the mosquitoes showed evidence of ability to transmit either genotype of CHIKV at 3 dpi. Further, at $18^{\circ} \mathrm{C}$ only Ae. albopictus infected with the ECSA genotype showed evidence of virus in saliva at 7 dpi. Overall, infection with the ECSA CHIKV genotype produced higher virus loads in mosquitoes compared to infection with the Asian CHIKV genotype. Our results suggest that lower ambient temperatures may impede transmission of some CHIKV strains by Ae. albopictus at early time points post infection.
\end{abstract}

Keywords: chikungunya; Aedes albopictus; vector competence; temperature; extrinsic incubation period 


\section{Introduction}

Chikungunya is a vector-borne disease that has caused recent outbreaks in tropical and sub-tropical regions of the world [1]. Though the disease is rarely fatal, it causes incapacitating arthralgia which can persist for months after infection [2]. There are three genotypes of chikungunya virus (CHIKV), classified according to original geographical distributions, known as Asian, East/Central/South African (ECSA) and West African [3]. The primary vector of CHIKV is Aedes aegypti [4]. A secondary vector, the Asian tiger mosquito, Ae. albopictus has been implicated in large, unprecedented outbreaks in tropical areas, and in the geographical expansion of CHIKV to temperate countries such as France and Italy $[5,6]$. Indeed, Ae. albopictus was the primary vector during the explosive outbreak that occurred on Reunion island [7] in 2005/2006, resulting in hundreds of thousands of cases [8]. The ability of Ae. albopictus to transmit the CHIKV strain, belonging to the ECSA genotype, was partly enhanced by mutations in the viral envelope 1 (E1) protein. Further transmission and dissemination of the mutated CHIKV in the Indian Ocean region led to the appearance of a new virus subgroup, the Indian Ocean Lineage (IOL). Mutations appearing in this lineage were later shown to allow replication to higher titers in the vector Ae. albopictus $[9,10]$.

Australia is a non-endemic country for CHIKV. However, the risk of CHIKV introductions into Australia is high due to the close proximity of CHIKV-endemic neighboring countries in the Asia-Pacific region [11], a dramatic increase in imported CHIKV viremic cases [12] and the presence of established populations of both Ae. aegypti and Ae. albopictus mosquitoes in parts of the state of Queensland. There is also the potential for Ae. albopictus mosquitoes, currently confined to the Torres Strait in north Queensland, to extend their geographical range and become established on the mainland $[13,14]$. Australian Ae. albopictus mosquitoes have also been shown to be highly competent vectors of the ECSA CHIKV genotype in the laboratory [15]. The Asian CHIKV genotype actively circulates in Australia's neighboring region [11] and recently caused an outbreak in New Caledonia [16]. A recent review on the vector competence of Aedes spp. for CHIKV indicated that, although the ECSA CHIKV genotype has been studied intensively, the ability of Ae. albopictus to transmit the Asian CHIKV genotype remains poorly characterized [17].

The interaction between vector and virus can impact the likelihood and magnitude of outbreaks. Vector/virus interactions are known to depend on various biotic (e.g., vector and viral genetics, vector and host competence, vector life-history traits) and abiotic (e.g., temperature, rainfall, humidity) factors [18-20]. Temperature is an important factor influencing vector ecology, vector competence and the extrinsic incubation period (EIP) of different viruses, including dengue virus (DENV) [21]. The ability of Ae. albopictus eggs to survive over winter conditions in temperate, southern Australian regions [22] and the threat of invasion of this mosquito necessitate an understanding of how lower temperatures may affect transmission of chikungunya, particularly at early time points in infection. A short EIP may necessitate faster deployment of vector control measures by public health authorities. We examined the potential for transmission at lower temperatures, using two different CHIKV genotypes, ECSA and Asian, and at 3- and 7-days post infection.

\section{Results}

\subsection{Survival Rates}

Mosquitoes were fed with infectious blood meals containing CHIKV belonging to either the ECSA or Asian genotypes at a final concentration of $1 \times 10^{7} \mathrm{pfu} / \mathrm{mL}$. They were then held at either $18{ }^{\circ} \mathrm{C}$ or $28{ }^{\circ} \mathrm{C}$ until 7 days post infection (dpi). At least $95 \%$ (number surviving/ total number of CHIKV-exposed; Table 1) of mosquitoes survived over the 7-day experiment. 
Table 1. Proportions of surviving Ae. albopictus mosquitoes that were orally challenged with either Asian or ECSA genotype CHIKV, and maintained at either $18^{\circ} \mathrm{C}$ or $28^{\circ} \mathrm{C}$.

\begin{tabular}{cccc}
\hline dpi & $\begin{array}{c}\text { Temperature } \\
{ }^{\circ} \mathbf{C}\end{array}$ & \multicolumn{2}{c}{$\%$ Survival } \\
& Asian & ECSA \\
\hline \multirow{2}{*}{3} & 18 & $100(20 / 20)$ & $100(20 / 20)$ \\
& 28 & $95(19 / 20)$ & $100(20 / 20)$ \\
\hline \multirow{2}{*}{7} & 18 & $95(19 / 20)$ & $100(20 / 20)$ \\
& 28 & $100(20 / 20)$ & $100(20 / 20)$ \\
\hline
\end{tabular}

$\mathrm{dpi}=$ days post infection; ${ }^{\text {a }}$ Percentage of surviving mosquitoes (number of surviving mosquitoes/total number of mosquitoes exposed).

\subsection{Effect of Temperature and Genotype on Infection, Dissemination and Transmission of CHIKV}

Infection rates (number of CHIKV RNA-positive bodies/total bodies tested) of mosquitoes challenged with infectious blood meals were consistently $100 \%$, at either $18{ }^{\circ} \mathrm{C}$ or $28^{\circ} \mathrm{C}$, and for both the ECSA and Asian genotypes (Table 2). Dissemination rates (number of CHIKV RNA-positive wings and legs/ total infected mosquitoes) were also consistently 100\%, irrespective of virus genotype or temperature (Table 2). However, there was no detectable virus in saliva of either virus genotype at $3 \mathrm{dpi}$ at $18^{\circ} \mathrm{C}$. At $7 \mathrm{dpi}$ and $18^{\circ} \mathrm{C}$, transmissibility (number of CHIKV-positive saliva/total infected mosquitoes) was only demonstrated for the ECSA genotype and by $25 \%$ of mosquitoes. At $28{ }^{\circ} \mathrm{C}$, the number of mosquitoes with virus in the saliva for the Asian CHIKV genotype approximately doubled, with an increasing extrinsic incubation period from 3 dpi $(10.53 \%, 2 / 19)$ to 7 dpi $(20 \%, 4 / 20)$ (Table 2). Similar numbers (20-25\%) of mosquitoes exhibited transmissibility of the ECSA CHIKV genotype across both days.

At $3 \mathrm{dpi}$, there was significantly higher transmissibility of the ECSA CHIKV genotype at $28^{\circ} \mathrm{C}$ than $18^{\circ} \mathrm{C}(p<0.05$ by Chi-Square; Table 2$)$. There was no significant difference in transmissibility percentages between the two genotypes when mosquitoes were sampled at $7 \mathrm{dpi}$ from the $28^{\circ} \mathrm{C}$ treatment (Table 2). At $7 \mathrm{dpi}$, there was a significantly higher percentage of mosquitoes infected with the ECSA genotype capable of transmission in saliva than mosquitoes infected with the Asian genotype $(p<0.05)$ when held at $18^{\circ} \mathrm{C}$. At $18{ }^{\circ} \mathrm{C}$, the ECSA CHIKV genotype displayed significantly higher transmissibility at 7 dpi than 3 dpi $(p<0.05)$.

Table 2. Infection, dissemination and transmissibility percentages of CHIKV from Asian and ECSA genotypes in Ae. albopictus maintained at either $18^{\circ} \mathrm{C}$ or $28^{\circ} \mathrm{C}$.

\begin{tabular}{cccccccc}
\hline dpi & \multirow{2}{*}{$\begin{array}{c}\text { Temperature } \\
{ }^{\circ} \text { C }\end{array}$} & \multicolumn{2}{c}{ \% Infection $^{\mathbf{a}}$} & \multicolumn{2}{c}{ \% Dissemination } & \multicolumn{2}{c}{ \% Transmissibility $^{\mathbf{c}}$} \\
& 18 & $100(20 / 20)$ & $100(20 / 20)$ & $100(20 / 20)$ & $100(20 / 20)$ & $0(0 / 20)$ & $0(0 / 20)$ \\
3 & 28 & $100(19 / 19)$ & $100(20 / 20)$ & $100(19 / 19)$ & $100(20 / 20)$ & $10.53(2 / 19)$ & $25(5 / 20)^{1}$ \\
\hline \multirow{2}{*}{7} & 18 & $100(19 / 19)$ & $100(20 / 20)$ & $100(19 / 19)$ & $100(20 / 20)$ & $0(0 / 19)$ & $25(5 / 20)^{2,3}$ \\
& 28 & $100(20 / 20)$ & $100(20 / 20)$ & $100(20 / 20)$ & $100(20 / 20)$ & $20(4 / 20)$ & $20(4 / 20)$ \\
\hline
\end{tabular}

$\mathrm{dpi}=$ days post infection; ${ }^{\text {a }}$ Percentage mosquitoes containing virus in their bodies (number of positive bodies/total tested); ${ }^{b}$ Percentage of mosquitoes disseminating CHIKV, containing virus in their wings and legs (number of positive leg/wing samples/ total infected mosquitoes); ${ }^{c}$ Percentage of mosquitoes containing virus in their saliva (number of positive saliva samples/total infected mosquitoes) and thus potentially capable of transmission; ${ }^{1} p<0.05$ by Chi-Square $\left(3 \mathrm{dpi} 18^{\circ} \mathrm{C}\right.$ vs $28^{\circ} \mathrm{C}$ ECSA $) i^{2} p<0.05$ by Chi-Square $\left(7 \mathrm{dpi} 18^{\circ} \mathrm{C}\right.$ ECSA vs Asian); ${ }^{3} p<0.05$ by Chi-Square (3 dpi vs 7 dpi $18^{\circ} \mathrm{C}$ ECSA).

\subsection{Effect of temperature and genotype on CHIKV RNA levels}

At 3 dpi, CHIKV load (RNA copies) in bodies of mosquitoes held at either temperature were determined by qRT-PCR. There were significantly higher viral RNA loads (1-2 logs difference) for the ECSA genotype than the Asian genotype virus at both $18^{\circ} \mathrm{C}$ and $28^{\circ} \mathrm{C}(p<0.0001$ by Mann-Whitney $\mathrm{U}$ test) (Figure 1A, Table 3). Further, there was a significantly higher viral load for the Asian genotype 
$\mathrm{CHIKV}$ at $28^{\circ} \mathrm{C}$ than $18{ }^{\circ} \mathrm{C}(p<0.0001)$ at $3 \mathrm{dpi}$. However, there was no statistically significant difference amongst ECSA viral loads between mosquitoes held for $3 \mathrm{dpi}$ at either $18{ }^{\circ} \mathrm{C}$ or $28^{\circ} \mathrm{C}$.

Table 3. CHIKV RNA copies detected in Ae. albopictus mosquitoes at 3 and 7 dpi.

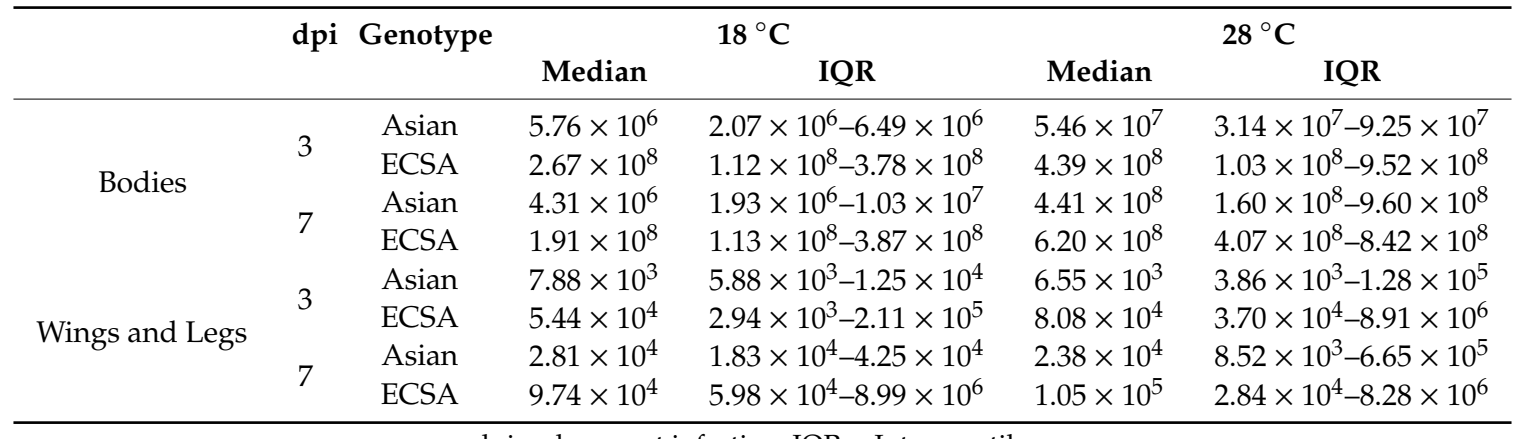

dpi $=$ days post infection, $\mathrm{IQR}=$ Interquartile range.
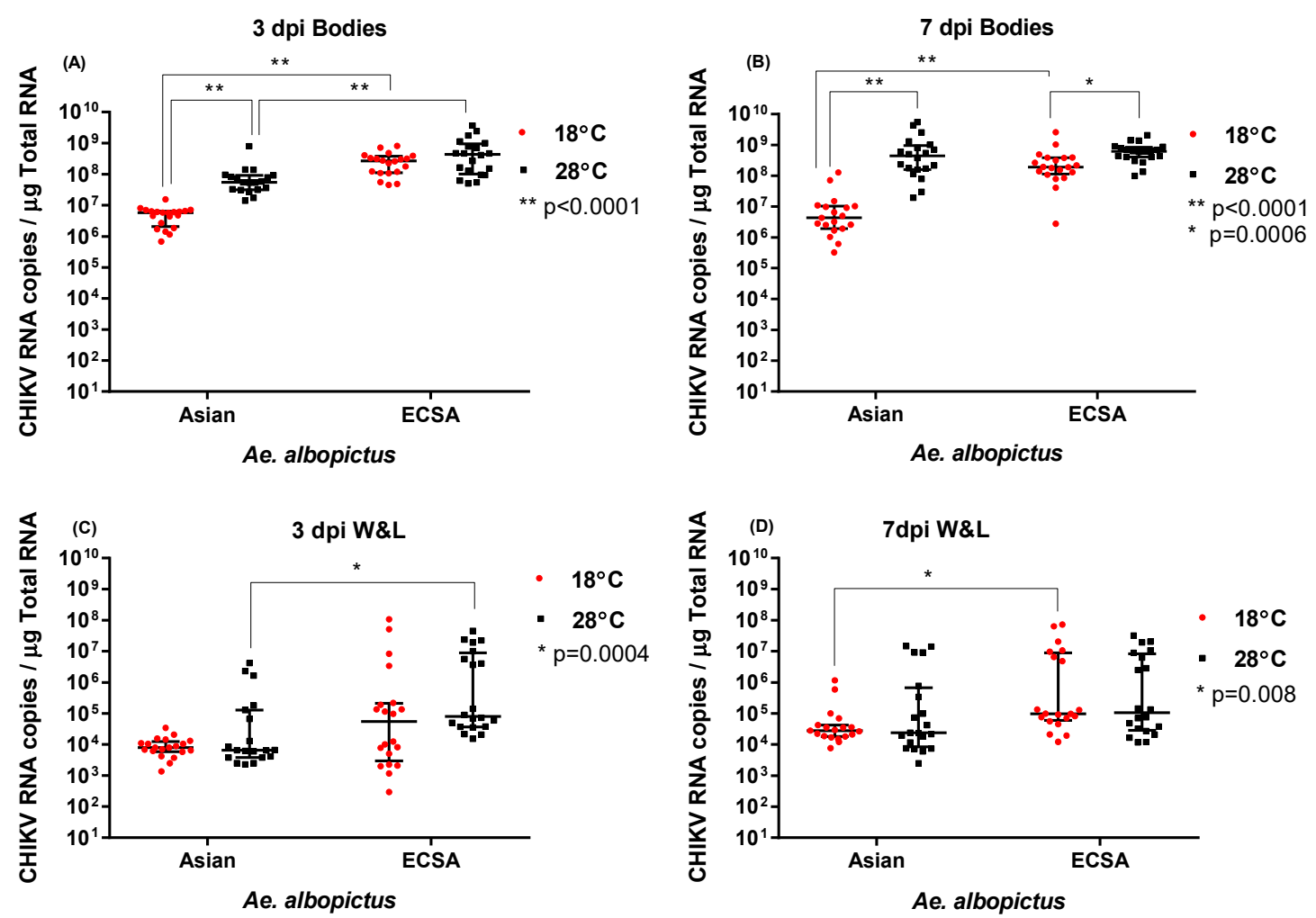

Figure 1. Asian and East/Central/South African (ECSA) genotype CHIKV RNA copies detected in bodies, wings and legs (A) CHIKV RNA copies in bodies at $18{ }^{\circ} \mathrm{C}$ and $28{ }^{\circ} \mathrm{C}, 3 \mathrm{dpi}$; (B) CHIKV RNA copies in bodies at 7 dpi across temperatures; (C) CHIKV RNA copies in wings (W) \& legs (L) at 3 dpi across temperatures; (D) CHIKV RNA copies in CHIKV wings (W) \& legs (L) at 7 dpi across temperatures; ${ }^{*}$ denotes statistical significance $(p<0.05)$.

Similar to the pattern observed at $3 \mathrm{dpi}$, ECSA CHIKV genotype had a significantly higher body viral load than CHIKV of Asian genotype at 7 dpi regardless of the temperature $(p=0.0007$, Mann Whitney test). At 7 dpi and for both genotypes, significantly higher viral loads were observed in mosquito bodies at $28^{\circ} \mathrm{C}$ than at $18^{\circ} \mathrm{C}(p<0.005)$ (Figure 1B, Table 3). Additionally, at $18^{\circ} \mathrm{C}, \mathrm{CHIKV}$ of ECSA genotype had a significantly higher body viral load than Asian CHIKV genotype $(p<0.0001)$ but, unlike the viral loads at $3 \mathrm{dpi}$, this was not the case at $28^{\circ} \mathrm{C}$.

For wings and legs, at 3 dpi we observed significantly higher viral loads for ECSA versus the Asian genotype at $28^{\circ} \mathrm{C}(p=0.0004)$, but not at $18^{\circ} \mathrm{C}$ (Figure $1 \mathrm{C}$ ). At $7 \mathrm{dpi}$, there was no significant 
difference in viral loads at $28^{\circ} \mathrm{C}$ for either genotype. However, we observed a significant difference between genotypes at $18^{\circ} \mathrm{C}$ in terms of viral loads, with ECSA being higher $(p=0.0008)$ (Figure $1 \mathrm{D}$ ). Notably, within each genotype, there was no significant difference in viral loads between temperatures, at either 3 dpi or 7 dpi. Overall, irrespective of the temperature, at both 3 dpi and 7 dpi, ECSA CHIKV genotype had higher viral loads in wings and legs than the Asian genotype $(p<0.0001$ and $p=0.0005$ respectively, Mann Whitney test).

\section{Discussion}

We found that, irrespective of being held at either $18{ }^{\circ} \mathrm{C}$ or $28^{\circ} \mathrm{C}$, Ae. albopictus from Australian Torres Strait Island populations are readily susceptible to infection and dissemination with the ECSA and Asian CHIKV genotype strains used in this study. Our finding is similar to results obtained from European and American Ae. albopictus populations [23]. We show that Torres Strait Ae. albopictus had $100 \%$ infection and dissemination rates at the early time points of 3 and $7 \mathrm{dpi}$ for both Asian and ECSA genotypes, at two different temperatures. A previous vector competence study conducted using mosquitoes from the Torres Strait found similar infection and dissemination rates $(92 \%)$ at $28^{\circ} \mathrm{C}$ for the ECSA genotype [15].

Maximum transmissibility of both Asian and ECSA genotypes was observed when mosquitoes were held at $28^{\circ} \mathrm{C}$ post infection. The mosquitoes used in our study exhibited a heterogeneous pattern in the transmissibility of virus at different temperatures and time points. This heterogeneous nature of transmissibility was also observed in Brazilian Ae. albopictus challenged with Asian CHIKV and sampled up to $12 \mathrm{dpi}$ [24]. In our study, at $28^{\circ} \mathrm{C}$, mosquitoes infected with the Asian genotype were better able to transmit virus at $7 \mathrm{dpi}$ than $3 \mathrm{dpi}$. The transmissibility rates observed in our study (20-25\%) are comparable to those observed in other populations, including Italian Ae. albopictus with percentage transmission rates of $23-36 \%$ for ECSA CHIKV [25]. A previous study of the Australian (Torres Strait) mosquito population (including Ae. albopictus) reported a rate of $32 \%$ when mosquitoes were held at $28^{\circ} \mathrm{C}$ for 14 days post infection [15], similar to the rates we report here.

Our results indicate that low ambient temperature delays saliva infection by CHIKV at early time points in these mosquitoes, despite high infection and dissemination rates at $3 \mathrm{dpi}$. The results suggest that both ECSA and Asian CHIKV genotypes are unable to cross the salivary gland barrier at $18^{\circ} \mathrm{C}$ during early time points post infection. However, the ECSA CHIKV strain was able to evade the salivary gland barrier at low temperatures by $7 \mathrm{dpi}$, possibly mediated by the higher levels of virus observed in mosquito bodies for this genotype when compared with the Asian strain. Previous studies have also found strong interactions between virus strain and temperature on transmission efficiency of CHIKV [26].

Overall, ECSA CHIKV genotype was able to replicate to a higher viral load than the Asian genotype, consistent with ECSA CHIKV being highly adapted to Ae. albopictus [10]. Further, across time points and temperatures, there was an overall pattern of greater transmissibility of ECSA versus Asian CHIKV genotypes. Most surveyed populations of Ae. albopictus are better able to transmit the ECSA CHIKV genotype than the Asian genotype [25,27-29], again consistent with virus adaptation to this vector. However, Australian Ae. albopictus also clearly has the potential to transmit Asian CHIKV at higher temperatures, similar to Ae. albopictus populations from America [23]. In our study, transmissibility rates at later time points and a higher temperature of $28{ }^{\circ} \mathrm{C}$ were the same between genotypes, suggesting Asian genotype strains pose a similar risk to ECSA ones in more tropical regions of Australia. At lower temperatures encountered in more temperate areas however, our results suggest that, of the strains tested, the ECSA genotype may pose the greater risk at earlier time points, with transmission of the Asian genotype likely more delayed. 


\section{Materials and Methods}

\subsection{Mosquitoes}

Ae. albopictus eggs were obtained from a colony established from eggs collected on Hammond Island, Torres Strait, Australia, in July 2014 and subsequently maintained in the QIMR Berghofer insectary. Eggs were hatched and larvae reared at a density of 400 individuals in $3 \mathrm{~L}$ of rainwater. Larvae were provided ground TetraMin Tropical Flakes fish food (Tetra, Melle, Germany) ad libitum. Pupae were transferred to a container of rainwater inside a $30 \times 30 \times 30 \mathrm{~cm}$ cage (BugDorm, MegaView Science Education Services Co., Taichung, Taiwan) for adult emergence. Adult mosquitoes were provided with $10 \%$ sucrose solution on cotton wool pledgets and kept at $27^{\circ} \mathrm{C}$.

\subsection{Virus Strains}

CHIKV strains of the ECSA and Asian genotypes were isolated from patients returning to Australia from Mauritius in 2006 and the Caribbean in 2014, respectively. Specifically, the CHIKV strains from the ECSA and Asian genotypes used in the study are available on GenBank (accession numbers EU404186 and MF773560, respectively). Viruses were propagated in C6/36 Ae. albopictus cells and maintained in RPMI-1640 medium (Sigma ${ }^{\circledR}$ Life Sciences, USA) supplemented with $2.5 \%$ fetal bovine serum following incubation at $28{ }^{\circ} \mathrm{C}$ for 2 days.

Plaque assays were performed to quantify the virus titer of stock virus. Vero (African Green Monkey Kidney) cells maintained in Dulbecco's Modified Eagle’s Medium (Sigma ${ }^{\circledR}$ Life Sciences, USA) supplemented with 10\% fetal bovine serum and 1\% GlutaMAX ${ }^{\mathrm{TM}}-1$ (Gibco ${ }^{\circledR}$ Life Technologies, USA) at $37{ }^{\circ} \mathrm{C}$ with $5 \% \mathrm{CO} 2$ were grown until $95 \%$ confluent in the 24-well tissue culture plates. Cell monolayers were infected with a tenfold serial dilution of the sample for $2 \mathrm{~h}$ at $37^{\circ} \mathrm{C}$. The overlay media, consisting of a 1:1 mix of double strength Medium 199 (Gibco ${ }^{\circledR}$ Life Technologies, USA) and 2\% low viscosity sodium Carboxy Methyl Cellulose (Sigma ${ }^{\circledR}$ Life Sciences, USA), was then added to each well. Plates were incubated for $2-3$ days at $37^{\circ} \mathrm{C}$ with $5 \% \mathrm{CO} 2$ until plaques became visible. Plaques were counted following fixation and staining for 3 hours in a $0.05 \%$ crystal violet (Sigma ${ }^{\circledR}$ Aldrich, USA) solution containing 1\% formaldehyde (Sigma-Aldrich, USA).

\subsection{Mosquito Oral Challenge}

Ae. albopictus mosquitoes were challenged with CHIKV using an infectious blood meal after depriving of $10 \%$ sucrose for $36 \mathrm{~h}$, and of water for $12 \mathrm{~h}$ prior to blood feeding. Briefly, 8 cups each containing 75-80 Ae. albopictus female mosquitoes, 4-7 days old, were exposed to blood meals consisting of defibrinated sheep blood (Serum Australis) and either CHIKV genotype at a final concentration of $1 \times 10^{7} \mathrm{pfu} / \mathrm{mL}$ for $90 \mathrm{~min}$ using an artificial membrane feeding system, fitted with a porcine intestinal membrane. Exposed mosquitoes were sorted on ice and fully engorged females were maintained in a 740 FLED environmental growth chamber (HiPoint, Taiwan) set to produce a constant temperature of $18^{\circ} \mathrm{C}$ or $28^{\circ} \mathrm{C}, 70 \% \mathrm{RH}$ and a variable light cycle (12:12 light: dark with $30 \mathrm{~min}$ dawn/dusk periods). The infectious blood meals were titrated as 10 -fold serial dilutions on 24 -well cell culture plates seeded with confluent Vero cell monolayers as described above.

At 3 and 7 days post infection, salivation assays were performed. Briefly, 20 mosquitoes were removed at each time point, anaesthetized with $\mathrm{CO}_{2}$, and dissected on ice. The wings and legs of each mosquito were removed, and the saliva collected by placing the proboscis into a $200 \mu \mathrm{L}$ pipette tip containing $40 \mu \mathrm{L}$ of medium consisting of $10 \%$ FBS and 10\% sucrose solution for $20 \mathrm{~min}$. Following collection of saliva, the bodies were retained. Tubes containing the mosquito bodies, the saliva-collection media and wings and legs were stored $-80{ }^{\circ} \mathrm{C}$ until assayed for virus by cell culture and/ or RNA extraction. 


\subsection{Nucleic Acid Extraction}

RNA was extracted from individual mosquito bodies or wings and legs using TRIzol ${ }^{\mathrm{TM}}$ reagent (Invitrogen ${ }^{\mathrm{TM}}$, Thermo Fisher Scientific, USA). Briefly, $500 \mu \mathrm{L}$ or $1000 \mu \mathrm{L}$ of Trizol was added to each $2 \mathrm{~mL}$ screw cap vial containing the individual mosquito wings and legs or body, respectively. The samples were homogenized using a MiniBeadbeater-96 (Biospec Products, Bartlesville, Oklahoma, USA) for $90 \mathrm{~s}$ after adding zirconium silica glass beads (Daintree Scientific, St Helens, TAS, Australia). Total RNA was extracted from the homogenate according to the manufacturer's specifications. RNA was dissolved in $40 \mu \mathrm{L}$ Ultrapure ${ }^{\mathrm{TM}}$ water (Invitrogen ${ }^{\mathrm{TM}}$, Thermo Fisher Scientific, USA), and frozen at $-80^{\circ} \mathrm{C}$ until further analysis.

\subsection{Quantitative RT-PCR to Detect CHIKV}

For absolute quantification of the CHIKV viral load, a control plasmid containing a cloned copy of the targeted fragment of the envelope protein E1 gene of CHIKV (nucleotides 792 to 853, GenBank accession number AM258995) was constructed. Briefly, viral RNA was extracted using the QIAamp ${ }^{\circledR}$ Viral RNA Mini Kit (Qiagen, Germany) and cDNA synthesized using the SuperScript ${ }^{\mathrm{TM}}$ III Reverse Transcriptase kit (Invitrogen ${ }^{\mathrm{TM}}$, Thermo Fisher Scientific, USA) according to the manufacturer's protocol. The targeted CHIKV fragment was amplified using CloneAmp ${ }^{\text {TM }}$ HiFi PCR Premix (Takara, Clontech Laboratories, USA), and cloned into the pUC19 plasmid vector (Genscript, New Jersey, United States) using the In-Fusion ${ }^{\circledR}$ Cloning Kit (Takara, Clontech Laboratories, USA) as described by the manufacturer. The presence of the insert DNA was confirmed by nucleotide sequencing. For qRT-PCR analysis, the plasmid was linearized by EcoRI (Promega, USA) and purified using the Nucleospin ${ }^{\circledR}$ Gel and PCR clean-up kit (Macherey-Nagel, Germany). The concentration and purity of the linearized plasmid DNA was determined using the NanoDrop Lite spectrophotometer (Thermo Fisher Scientific, USA). The plasmid copy number was calculated based on the measured DNA concentration and its molecular weight. Plasmid DNA concentrations were confirmed prior to the preparation of a 10 -fold serial dilution from $10^{7}$ to $10^{2}$ copies $/ \mu \mathrm{L}$ and run in parallel with the samples in all quantitative real time PCRs (qRT-PCR).

One-step qRT-PCR, targeting the CHIKV structural envelope glycoprotein E1 was performed to quantify CHIKV RNA present in mosquito samples. The, TaqMan ${ }^{\circledR}$ Fast Virus 1-Step Master Mix (Applied Biosystems, USA) was used according to the manufacturer's protocol. A final reaction volume of $20 \mu \mathrm{L}$ included $2 \mu \mathrm{L}$ RNA extract, $4 \times$ TaqMan ${ }^{\circledR}$ Fast Virus 1-Step Master Mix, $400 \mathrm{nM}$ of each primer (CHIKV forward primer 5'-CCCGGTAAGAGCGGTGAA-3', CHIKV reverse primer $5^{\prime}$-CTTCCGGTATGTCGATGGAGAT-3'), $250 \mathrm{nM}$ of probe (5' FAM-TGCGCCGTAGGGAAC ATGCC-BHQ1 3') and Ultrapure ${ }^{\mathrm{TM}}$ water (Invitrogen ${ }^{\mathrm{TM}}$, Thermo Fisher Scientific, USA). The probe and primer pairs (Macrogen, Korea) were selected as previously described [15]. Amplification was performed in the Rotor-Gene ${ }^{\mathrm{TM}} \mathrm{Q}$ Real-Time PCR system (Qiagen ${ }^{\circledR}$, Hilden, Germany), using the thermal cycle: $50{ }^{\circ} \mathrm{C}$ for $5 \mathrm{~min}, 95^{\circ} \mathrm{C}$ for $20 \mathrm{~s}$, and 40 repetitions of $95^{\circ} \mathrm{C}$ for $3 \mathrm{~s}$ and $60{ }^{\circ} \mathrm{C}$ for 30 s. A 10 -fold serial dilution of linearized control plasmid DNA and negative controls (without template), were included in each run. Data were analyzed and quantified using the Rotor-Gene ${ }^{\mathrm{TM}} \mathrm{Q}$ software (Qiagen ${ }^{\circledR}$, Hilden, Germany). Samples in which CHIKV failed to amplify were classified as negative following confirmation of the presence of mosquito nucleic acid by amplification of the Ae. albopictus housekeeping gene RpS7 (Genbank accession number XM_019671546) using the GoTaq ${ }^{\circledR}$ 1-Step RT-qPCR System (Promega, Madison, WI, USA), as per manufacturer's recommendations, in the same Rotor-Gene PCR system. The reactions were carried out in a final reaction volume of 20 $\mu \mathrm{L}$ containing $2 \mu \mathrm{L}$ of extracted RNA, $250 \times$ GoScript $^{\text {TM }}$ RT Mix, $2 \times$ GoTaq $^{\circledR}$ qPCR Master Mix, 200 nM of each RpS7 F: 5'-CTCTGACCGCTGTGTACGAT-3', R: 5'-CAATGGTGGTCTGCTGGTTC-3' and Ultrapure $^{\mathrm{TM}}$ water (Invitrogen ${ }^{\mathrm{TM}}$, Life Technologies, USA). The cycling conditions consisted of 1 cycle at $50{ }^{\circ} \mathrm{C}$ for $5 \mathrm{~min}$ and $95^{\circ} \mathrm{C}$ for $2 \mathrm{~min}$, followed by 40 amplification cycles of $95^{\circ} \mathrm{C}$ for $15 \mathrm{~s}, 60^{\circ} \mathrm{C}$ for $30 \mathrm{~s}$ and $72{ }^{\circ} \mathrm{C}$ for $20 \mathrm{~s}$. Melt curve analysis was performed to analyze the specificity of the reaction. 


\subsection{Cytopathic Effect in Cell Culture}

The presence of infectious virus in mosquito saliva samples were detected as follows. In a 96-well microtiter plate, C6/36 cells were grown up to a 90\% confluency in RPMI 1640 media supplemented with L-glutamine, 2.5\% heat denatured FBS, $1 \times$ Antibiotic-Antimycotic (Gibco ${ }^{\circledR}$ Life Technologies, USA). Twenty $\mu \mathrm{L}$ of the saliva expectorate from each sample was inoculated into these wells and maintained at $28{ }^{\circ} \mathrm{C}$ for 5 days. The supernatants of the wells were transferred into a 24 -well plate seeded with $\sim 90 \%$ confluent monolayers of Vero cells and numbered with corresponding sample identification. Cytopathic effect was assessed after incubating the plates at $37^{\circ} \mathrm{C}, 5 \% \mathrm{CO}_{2}$ for 3 days. Supernatants of cells showing CPE were harvested and stored at $-80^{\circ} \mathrm{C}$ until confirmation of the presence of CHIKV in saliva expectorates. Briefly, viral RNA was extracted from cell culture supernatants using the High Pure Viral RNA kit (Roche diagnostics, NSW, Australia) according to the manufacturer's specifications. qRT-PCR for the detection of CHIKV RNA were performed using the GoTaq ${ }^{\circledR}$ 1-Step RT-qPCR System (Promega, Madison, WI, USA) and CHIKV-specific primers as described above.

\subsection{Data Analysis}

Survival, infection, dissemination and transmission rates were calculated for each dpi, and for each genotype at both $18{ }^{\circ} \mathrm{C}$ and $28^{\circ} \mathrm{C}$ using the equations mentioned within the results section. The statistical significance of viral loads was tested by Fisher's exact test, Mann Whitney test along with the column statistics including median and interquartile range (IQR) and Chi square tests using GraphPad Prism ${ }^{\circledR}$ Version 7.00 (GraphPad Software, La Jolla, California USA, 2008).

\section{Conclusions}

Australian Ae. albopictus displayed similar infection and dissemination rates of CHIKV belonging to the ECSA and Asian genotypes, irrespective of day post infection or temperature. In our experiments, transmission at a low temperature of $18{ }^{\circ} \mathrm{C}$ was notably absent by $7 \mathrm{dpi}$ for the Asian but not the ECSA CHIKV genotype. At the higher temperature of $28^{\circ} \mathrm{C}$, mosquitoes were able to transmit both genotypes equally well by day $7 \mathrm{dpi}$, compared to $3 \mathrm{dpi}$, where there was evidence of increased transmission of the ECSA genotype. In the face of the continued global spread of CHIKV and increased risk of incursion into non-endemic regions [11,12,30], our results further the understanding of the potential susceptibility of Ae. albopictus to different CHIKV genotypes under varied temperature conditions. Coupled with the expansion of Aedes mosquitoes globally, and the specific risk of invasion of Ae. albopictus onto mainland Australia, these findings may aid in the formulation of more effective public health management strategies for this important arbovirus.

Author Contributions: Conceptualization, B.M.C.R.W.-Y., W.H., L.Y., E.A.M., A.T.P., G.J.D. and F.D.F.; formal analysis, B.M.C.R.W.-Y.; funding acquisition, W.H., L.Y., E.A.M., A.T.P., C.C.J., G.J.D. and F.D.F.; investigation, B.M.C.R.W.-Y., L.S. and F.D.F.; methodology, B.M.C.R.W.-Y., L.S., C.C.J., G.J.D. and F.D.F.; project administration, F.D.F.; supervision, F.D.F.; visualization, B.M.C.R.W.-Y.; writing—original draft, B.M.C.R.W.-Y.; writing一review \& editing, B.M.C.R.W.-Y., L.S., W.H., L.Y., E.A.M., A.T.P., C.C.J., G.J.D. and F.D.F.

Funding: This research was funded by National Health and Medical Research Council (NHMRC) of Australia, project grant APP1125317 and BMC Randika Wimalasiri-Yapa is funded by the University Grants Commission, Sri Lanka, The Open University of Sri Lanka and Queensland University of Technology, Brisbane, Australia.

Acknowledgments: We thank Henry Simila for technical assistance and Louise Hafner for useful guidance and pastoral care provided to B.W-Y during her PhD.

Conflicts of Interest: The authors declare they have no conflict of interest.

\section{References}

1. Fischer, D.; Thomas, S.M.; Suk, J.E.; Sudre, B.; Hess, A.; Tjaden, N.B.; Beierkuhnlein, C.; Semenza, J.C. Climate change effects on Chikungunya transmission in Europe: Geospatial analysis of vector's climatic suitability and virus' temperature requirements. Int. J. Health Geogr. 2013, 12, 51. [CrossRef] [PubMed] 
2. Manimunda, S.P.; Vijayachari, P.; Uppoor, R.; Sugunan, A.P.; Singh, S.S.; Rai, S.K.; Sudeep, A.B.; Muruganandam, N.; Chaitanya, I.K.; Guruprasad, D.R. Clinical progression of Chikungunya fever during acute and chronic arthritic stages and the changes in joint morphology as revealed by imaging. Trans. R. Soc. Trop. Med. Hyg. 2010, 104, 392-399. [CrossRef] [PubMed]

3. Powers, A.M.; Brault, A.C.; Tesh, R.B.; Weaver, S.C. Re-emergence of Chikungunya and O'nyong-nyong viruses: Evidence for distinct geographical lineages and distant evolutionary relationships. J. Gen. Virol. 2000, 81, 471-479. [CrossRef] [PubMed]

4. Lumsden, W.H.R. An epidemic of virus disease in Southern Province, Tanganyika Territory, in 1952-1953. I. Clinical features. Trans. R. Soc. Trop. Med. Hyg. 1955, 49, 28-32. [CrossRef]

5. Rezza, G. Chikungunya is back in Italy: 2007-2017. J. Travel Med. 2018, 25. [CrossRef] [PubMed]

6. European Centre for Disease Prevention and Control. Cluster of Autochtonous Chikungunya Cases in France; ECDC: Stockholm, Sweden, 23 August 2017.

7. Reiter, P.; Fontenille, D.; Paupy, C. Aedes albopictus as an epidemic vector of Chikungunya virus: Another emerging problem? Lancet Infect. Dis. 2006, 6, 463-464. [CrossRef]

8. Borgherini, G.; Poubeau, P.; Staikowsky, F.; Lory, M.; Moullec, N.L.; Becquart, J.P.; Wengling, C.; Michault, A.; Paganin, F. Outbreak of Chikungunya on Reunion island: Early clinical and laboratory features in 157 adult patients. Clin. Infect. Dis. 2007, 44, 1401-1407. [CrossRef] [PubMed]

9. Schuffenecker, I.; Iteman, I.; Michault, A.; Murri, S.; Frangeul, L.; Vaney, M.C.; Lavenir, R.; Pardigon, N.; Reynes, J.M.; Pettinelli, F.; et al. Genome microevolution of Chikungunya viruses causing the Indian Ocean outbreak. PLoS Med. 2006, 3, e263. [CrossRef]

10. Tsetsarkin, K.A.; Vanlandingham, D.; McGee, C.E.; Higgs, S. A single mutation in chikungunya virus affects vector specificity and epidemic potential. PLoS Pathog. 2007, 3, e201. [CrossRef]

11. Wimalasiri-Yapa, B.M.C.R.; Stassen, L.; Huang, X.; Hafner, L.M.; Hu, W.; Devine, G.J.; Yakob, L.; Jansen, C.C.; Faddy, H.M.; Viennet, E.; et al. Chikungunya virus in Asia-Pacific: A systematic review. Emerg. Microbes Infect. 2019, 8, 70-79. [CrossRef]

12. Huang, X.; Hu, W.; Yakob, L.; Devine, G.J.; McGraw, E.A.; Jansen, C.C.; Faddy, H.M.; Frentiu, F.D. El Niño southern oscillation, overseas arrivals and imported Chikungunya cases in Australia: A time series analysis. PLoS Negl. Trop. Dis. 2019, 13, 0007376. [CrossRef] [PubMed]

13. Viennet, E.; Knope, K.; Faddy, H.M.; Williams, C.R.; Harley, D. Assessing the threat of Chikungunya virus emergence in Australia. Commun. Dis. Intell. Q Rep. 2013, 37, E136-E143. [PubMed]

14. Hill, M.P.; Axford, J.K.; Hoffmann, A.A. Predicting the spread of Aedes albopictus in Australia under current and future climates: Multiple approaches and datasets to incorporate potential evolutionary divergence. Austral Ecol. 2014, 39, 469-478. [CrossRef]

15. Van den Hurk, A.F.; Hall-Mendelin, S.; Pyke, A.T.; Smith, G.A.; Mackenzie, J.S. Vector competence of Australian mosquitoes for Chikungunya virus. Vector Borne Zoonotic Dis. 2010, 10, 489-495. [CrossRef] [PubMed]

16. Dupont-Rouzeyrol, M.; Caro, V.; Guillaumot, L.; Vazeille, M.; D’Ortenzio, E.; Thiberge, J.-M.; Baroux, N.; Gourinat, A.-C.; Grandadam, M.; Failloux, A.-B. Chikungunya virus and the mosquito vector Aedes aegypti in New Caledonia (south pacific region). Vector Borne Zoonotic Dis. 2012, 12, 1036-1041. [CrossRef] [PubMed]

17. Christofferson, R.C.; Chisenhall, D.M.; Wearing, H.J.; Mores, C.N. Chikungunya viral fitness measures within the vector and subsequent transmission potential. PLoS ONE 2014, 9, e110538. [CrossRef] [PubMed]

18. Coffey, L.L.; Failloux, A.B.; Weaver, S.C. Chikungunya virus-vector interactions. Viruses 2014, 6, 4628-4663. [CrossRef] [PubMed]

19. Kramer, L.D.; Ciota, A.T. Dissecting vectorial capacity for mosquito-borne viruses. Curr. Opin. Virol. 2015, 15, 112-118. [CrossRef] [PubMed]

20. Lounibos, L.P.; Kramer, L.D. Invasiveness of Aedes aegypti and Aedes albopictus and vectorial capacity for Chikungunya virus. J. Infect. Dis. 2016, 214, S453-S458. [CrossRef] [PubMed]

21. Xu, L.; Stige, L.C.; Chan, K.-S.; Zhou, J.; Yang, J.; Sang, S.; Wang, M.; Yang, Z.; Yan, Z.; Jiang, T.; et al. Climate variation drives Dengue dynamics. Proc. Natl. Acad. Sci. USA 2017, 114, 113-118. [CrossRef] [PubMed]

22. Nicholson, J.; Ritchie, S.A.; Russell, R.C.; Zalucki, M.P.; Van Den Hurk, A.F. Ability for Aedes albopictus (Diptera: Culicidae) to survive at the climatic limits of its potential range in eastern Australia. J. Med. Entomol. 2014, 51, 948-957. [CrossRef] [PubMed] 
23. Vega-Rúa, A.; Lourenço-de-Oliveira, R.; Mousson, L.; Vazeille, M.; Fuchs, S.; Yébakima, A.; Gustave, J.; Girod, R.; Dusfour, I.; Leparc-Goffart, I.; et al. Chikungunya virus transmission potential by local Aedes mosquitoes in the Americas and Europe. PLoS Negl. Trop. Dis. 2015, 9, e0003780. [CrossRef] [PubMed]

24. Honório, N.A.; Wiggins, K.; Câmara, D.C.P.; Eastmond, B.; Alto, B.W. Chikungunya virus vector competency of Brazilian and Florida mosquito vectors. PLoS Negl. Trop. Dis. 2018, 12, e0006521. [CrossRef] [PubMed]

25. Severini, F.; Boccolini, D.; Fortuna, C.; Di Luca, M.; Toma, L.; Amendola, A.; Benedetti, E.; Minelli, G.; Romi, R.; Venturi, G.; et al. Vector competence of Italian Aedes albopictus populations for the Chikungunya virus (E1-226V). PLoS Negl. Trop. Dis. 2018, 12, e0006435. [CrossRef] [PubMed]

26. Zouache, K.; Fontaine, A.; Vega-Rua, A.; Mousson, L.; Thiberge, J.M.; De-Oliveira, R.L.; Caro, V.; Lambrechts, L.; Failloux, A.B. Three-way interactions between mosquito population, viral strain and temperature underlying Chikungunya virus transmission potential. Proc. Biol. Sci. 2014, 281. [CrossRef] [PubMed]

27. Alto, B.W.; Wiggins, K.; Eastmond, B.; Velez, D.; Lounibos, L.P.; Lord, C.C. Transmission risk of two Chikungunya lineages by invasive mosquito vectors from Florida and the Dominican Republic. PLoS Negl. Trop. Dis. 2017, 11, e0005724. [CrossRef]

28. Sam, I.C.; Loong, S.-K.; Michael, J.C.; Chua, C.-L.; Wan, S.W.Y.; Vythilingam, I.; Chan, S.-Y.; Chiam, C.-W.; Yeong, Y.-S.; AbuBakar, S.; et al. Genotypic and phenotypic characterization of Chikungunya virus of different genotypes from Malaysia. PLoS ONE 2012, 7, e50476. [CrossRef]

29. Vega-Rúa, A.; Zouache, K.; Girod, R.; Failloux, A.-B.; Lourenço-de-Oliveira, R. High level of vector competence of Aedes aegypti and Aedes albopictus from ten American countries as a crucial factor in the spread of Chikungunya virus. J. Virol. 2014, 88, 6294-6306. [CrossRef]

30. Furuya-Kanamori, L.; Liang, S.; Milinovich, G.; Magalhaes, R.J.; Clements, A.C.; Hu, W.; Brasil, P.; Frentiu, F.D.; Dunning, R.; Yakob, L. Co-distribution and co-infection of chikungunya and dengue viruses. BMC Infect. Dis. 2016, 16, 84. [CrossRef]

(C) 2019 by the authors. Licensee MDPI, Basel, Switzerland. This article is an open access article distributed under the terms and conditions of the Creative Commons Attribution (CC BY) license (http://creativecommons.org/licenses/by/4.0/). 